\title{
A loucura de Hamlet ${ }^{1}$
}

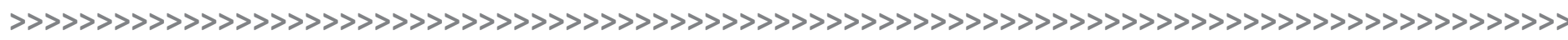

Pedro Vieira*

Desde que o livro Hamlet, a mais longa e uma das mais conhecidas obras de William Shakespeare, foi publicado e encenado, temos vários registros de pesquisas sobre a loucura de Ofélia e de Hamlet. E é sobre a loucura do último que versa o presente ensaio. Faz-se necessário esclarecer que não há intenção alguma de criticar a genialidade da peça de Shakespeare. Além disso, é importante salientar que o presente ensaio tem o intuito de fazer uma leitura contemporânea da obra; afinal, as doenças citadas ao longo deste texto não eram ainda reconhecidas na época em que a peça foi escrita.

Shakespeare recorria bastante à questão do sobrenatural, porém sempre deixava pequenas brechas ou incertezas nas peças, para que o leitor ou espectador pudesse se divertir sozinho em seus pensamentos, como em Sonhos de uma noite de verão, em que se vê uma aventura mágica vivida pelas personagens durante uma noite, e, no dia seguinte, quando todos acordam, nenhum deles entende se tudo de fato aconteceu ou se foi um sonho. Em Hamlet, ele não fez diferente: apresenta-nos um personagem descontrolado, que 'finge' ser louco. Cabe retomar, aqui, que este ensaio faz uma leitura atual e realista ${ }^{2}$ da obra, assim sendo, pode-se observar que o príncipe Hamlet, por várias vezes, mostra sinais de loucura, mesmo repetindo que tudo é apenas uma farsa, uma parte de seu plano de vingança. Essa farsa, aliás, tem início porque um fantasma o orientou a agir de tal modo, o que pode ser tratado como insanidade, visto que não há evidências de que fantasmas existem. Além do mais, é comum que uma pessoa fora de si afirme e insista, pelo tempo que for, que tem plena consciência de seus atos.

O príncipe recebe a notícia de que o fantasma de seu pai vaga ainda pelo castelo na primeira cena. Portanto não é o único a vê-lo, mas podemos descartar, logo em seguida, a hipótese do sobrenatural. Explico: histórias como estas (em que se enxergam assombrações) sempre foram muito comuns. Na situação em que todos se encontravam - tensos pela recente e inesperada morte do rei -, é muito fácil e completamente normal criar histórias e ver coisas, tudo pela ansiedade e pelo medo do desconhecido. Hamlet é o único que conversa com o fantasma do rei, o qual o orienta a se vingar do assassino, e é nesse momento, logo no início da história, que notamos o primeiro traço da esquizofrenia sofrida pelo príncipe: escutar voz de comando.

No decorrer da peça, Hamlet mostra-se agressivo e continua tendo alucinações. Ele também demonstra sofrer do Complexo de Édipo ${ }^{3}$, complexo que voltou provavelmente após a morte do rei, pois, enquanto seu pai estava vivo, Hamlet apenas espelhava-se nele; e, depois de sua morte, o príncipe sente que deve substituí-lo e se apaixona pela própria mãe, exatamente como Freud descreve o complexo.

$\mathrm{Na}$ cena IV do terceiro ato, temos o ápice da loucura do protagonista. É quando tudo se une: surto psicótico (alucinações visuais e auditivas, agressividade, medo, sensação de estar sendo controlado); e o personagem evidencia o Complexo de Édipo, porque age como se sua mãe fosse sua esposa. Nessa cena, vemos que só quem vê e houve o fantasma do rei é o príncipe, pois está num quarto com a rainha e ela nada vê ou escuta. O pico da loucura é quando Hamlet acredita que o tio está escondido atrás da cortina, e, sob a voz

$1>$ A primeira versão deste ensaio foi produzida durante a disciplina eletiva intitulada Shakespeare e cinema, ministrada para alunos do Ensino Médio do Colégio de Aplicação da UFRGS pela professora Daniela Favero Netto, no primeiro semestre de 2012; o ensaio foi reescrito em 2013, para publicação.

* > Aluno do terceiro ano do Ensino Médio do Colégio de Aplicação em 2013. E-mail: (pedro.vieira1909@gmail.com). Daniela Favero Netto é a professora orientadora deste trabalho. Ela é Professora de Língua Portuguesa e Literatura no Colégio de Aplicação da UFRGS

$2>0$ termo realista é utilizado no sentido de buscar a proximidade com a realidade, com o concreto, evitando-se abstrações.

3 > O Complexo de Édipo: quando a criança atinge o período sexual fálico, na segunda infância, e dá-se então conta da diferença entre os sexos, tendendo a fixar a sua atenção libidinosa nas pessoas do sexo oposto no ambiente familiar. Disponível em: http://pt.wikipedia.org/ wiki/Complexo_de_Édipo. Acesso em: 19. mar. 2013. 
4 > Pois foi o tipo de interpretação que se optou fazer (mesmo entendendo-se que Shakespeare fez literatura, arte, e que, portanto, não tinha um compromisso com a realidade). de comando do rei Hamlet, desfere um golpe contra a pessoa escondida que, na verdade, era o pai de Ofélia. Mesmo assim, Hamlet não sente remorso, já que acredita que o que fez não é errado, ou seja, ele pensa estar ajudando o rei ao eliminar qualquer intruso que impeça sua vingança. Logo após isso, o fantasma do rei pede para Hamlet não deixar que Gertrudes se corrompa, passando uma noite a mais que seja, ao lado do irmão traidor. O fantasma vai embora, e o príncipe tenta fazer com que sua mãe o veja, mas ela não enxerga o mesmo que Hamlet. A partir de então, o diálogo que começa a se desenvolver entre Hamlet e Gertrudes já não parece mais ser entre mãe e filho, mas entre marido e mulher. Hamlet insiste que sua mãe não durma mais ao lado de seu tio e que ela não permita que ele sequer a toque; repreende-a severamente por todos os erros que cometeu e dá ordens à rainha como se fosse o rei.

Analisando-se a obra em busca de verossimilhança ${ }^{4}$, pode-se ver que, independentemente de sua intenção, Shakespeare criou um personagem desequilibrado (na verdade, esquizofrênico) e o levou ao público de um modo que sempre chamou mais atenção, qual seja: lançando mão de elementos que remetem ao sobrenatural, como a aparição do rei Hamlet e as conversas entre o príncipe, vivo, e o rei, morto.

Provavelmente, essa escolha tenha se dado não só por chamar atenção do leitor (ou público), mas também porque na época era a hipótese em que se acreditava quando se encontrava uma pessoa nas condições de Hamlet. O príncipe passa a obra inteira preso ao fantasma de seu pai e só descansa no momento de sua própria morte, quando consegue finalmente alcançar a vingança, que sempre foi seu grande objetivo, desde a morte do pai.

Nota-se que, naquela época, as crenças no sobrenatural exerciam muita força sobre a população, o que é diferente nos dias de hoje, com o desenvolvimento da ciência. Ainda, é importante perceber o quão interessante é o fato de - antes de se falar em Complexo de Édipo e em esquizofrenia - os sintomas serem reconhecidos e descritos com precisão na obra de Shakespeare, mesmo atribuindo-se a culpa a outro tipo de mal: a vingança.

\section{Referências:}

COMPLEXO DE ÉDIPO. In: WIKIPÉDIA, a enciclopédia livre. Flórida: Wikimedia Foundation, 2014. Disponível em: <http://pt.wikipedia.org/w/index.php?title=Complexo_de_\%C3\%89dipo\&oldid=39880031>. Acesso em: 19 mar. 2013.

SHAKESPEARE, William. Hamlet. 2. ed. São Paulo: Scipione, 2005. 